Effects of Coating Treatment with Aloe Vera and Glycerol on Germination Delay and Seed Viability of Wheat under Different Water Levels

\author{
Mustafa YILDIRIM \\ University of Kahramanmaraş Sutcu Imam, Agricultural Faculty, Department of Field Crops, Kahramanmaraş \\ https://orcid.org/0000-0002-9523-4007 \\ $\bowtie:$ m.yildirim@ksu.edu.tr
}

\begin{abstract}
This study was conducted to demonstrate the effect of seed coating on preventing early germination to decrease possible seed damage. For this aim, bread wheat seeds were coated with Aloe vera and glycerol to determine how these substances can preserve seed viability by avoiding early germination. The seeds were coated with 5 different concentrations of Aloe vera or glycerol and irrigated with varies water levels. Water absorption and germination rates, seed viability after five days, and germination vigor following the second irrigation were determined. The seeds coated with glycerol absorbed the least amount of water. This was followed by seeds coated with Aloe vera and uncoated control seeds, respectively. Five hours after the initial irrigation, seeds coated with $100 \%$ and $80 \%$ of glycerol absorbed the least amount of water of $9.15 \%$ and $14.85 \%$, respectively. Seeds coated with $100 \%$ and $80 \%$ of Aloe vera absorbed slightly more water of $23.96 \%$ and $29.01 \%$, respectively. More concentrated coatings of Aloe vera and glycerol were associated with lower germination rates but glycerol-coated seeds generally had the longest viability. Both coating treatments effectively preserved seed viability by delaying germination at low water levels.
\end{abstract}

\section{Research Article}

$\begin{array}{ll}\text { Article History } & \\ \text { Received } & : 16.02 .2020 \\ \text { Accepted } & : 06.04 .2020\end{array}$

\section{Keywords}

Aloe Vera

Germination

Glycerol

Coating

Wheat Seed

\title{
Aloe Vera ve Gliserol ile Kaplama İşleminin Buğdayın Farklı Su Seviyeleri Altında Çimlenme Gecikmesi ve Tohum Canlllığ Üzerine Etkileri
}

\section{ÖZET}

Düşük yağışla ıslanmış toprak çimlenme için yeterli olabilir fakat çimlendirilmiş tohumun canlılığının korunması için yeterli değildir. Bu nedenle, tohum kaplama uygulamasının çimlenmeyi geciktireceği ve bu riski azaltacağı düşünülerek bu çalışma yapılmıştır. Ekmeklik buğday tohumları, erken çimlenmeyi önleyerek tohum canlılığını ne kadar iyi koruduğunu belirlemek için Aloe vera ve gliserol ile kaplanmıştır. Tohumlar, kontrol tohumları hariç 5 farklı Aloe vera ve gliserol konsantrasyonu ile kaplanmış ve değişken miktarda su ile sulanmıştır. Su emme ve çimlenme oranları, 5 gün sonra canlılık ve ikinci bir sulama sonrasında çimlenme gücü ölçülmüştür. Gliserol ile kaplanan tohumlar en az suyu emmiş ve bunu Aloe vera ile kaplanmış tohumlar ve daha sonra kaplanmamış kontrol tohumları takip etmiştir. İlk sulamadan 5 saat sonra, \%100 ve \% 80 gliserol çözeltileri ile kaplanmış tohumlar en az suyu emmiştir (sırasıyla\% 9.15 ve \% 14.85). \%100 ve \%80 Aloe vera çözeltileri ile kaplanmış tohumlar, biraz daha fazla su emmiştir (sırasıyla\%23.96 ve \%29.01). Aloe vera ve gliserolün daha yoğun kaplamaları daha düşük çimlenme oranları ile ilişkili iken gliserol kaplı tohumlar genellikle en uzun yaşayabilirliğe sahip bulunmuştur. Her iki kaplama işlemi de düşük su seviyelerinde çimlenmeyi geciktirerek tohum canlılığını etkili bir şekilde korumuştur.

\section{Araştırma Makalesi}

\author{
Makale Tarihçesi \\ Geliş Tarihi : 16.02 .2020 \\ Kabul Tarihi : 06.04 .2020
}

Anahtar Kelimeler

Aloe Vera

Çimlenme

Gliserol

Kaplama

Buğday Tohumu

To Cite : Yıldırım M 2020. Effects of Coating Treatment with Aloe Vera and Glycerol on Germination Delay and Seed Viability of Wheat under Different Water Levels. KSU J. Agric Nat 23 (4): 994-1004. DOI: 10.18016/ksutarimdoga.vi.688270. 


\section{INTRODUCTION}

Cool-climate cereals represent the group of crops widely cultivated for human consumption. Most of these cereals are cultivated in semi-arid regions under rain-fed conditions (Mathre and Johnston, 1991). According to recent foresight, nearly $25 \%$ of all agricultural areas in the world are exposed under water stress (Khayatnezhad et al., 2010). During the germination (Abdoli and Mohsen, 2012) and early development periods (Almaghrabi, 2012) of coolclimate cereals grown in these areas, water is one of the most important limiting factors (Zaefizadeh et al., 2011). The often irregular and limited amount of rain in arid and semi-arid climates can adversely affect the germination of seeds. Therefore, the dates of crop sowing in such regions is important. For this reason, farmers generally plant their seeds either in dry soil before the first rain (Mathre and Johnston, 1991; Wuest and Lutcher, 2012), or in heavy soils after the first rain. After the first rain, seeds absorb water and expand within a few hours. However, when there are no additional rains, and the weather is dry and warm (because of evaporation), the seeds are unable to continue absorbing water. In the case of both sowing methods, seeds whose germination are interrupted under irregular weather conditions will remain within the soil in a swollen or partly germinated or dry (Eskandari, 2013) for a long period of time. This period can expend for weeks or even months. During this time, seeds that absorb water are exposed to soil fungi (Mathre and Johnston, 1991). These adverse environmental conditions that diminish the germination of seeds after their initial water uptake and growth are called "alatav" in Turkish. This phenomenon can be observed in all arid and semi-arid regions of world and can cause significant losses in yield by preventing the germination in many areas.

Many different studies were conducted to date on seed coating methods and seed priming. Seed coating has been used extensively for many years in ornamentals, forest plants, vegetables, and field crops (Corlett et al., 2014). It was used to increase the seeds' drought resistance (Kulkarni and Deshpande, 2007; Sayar et al., 2010; Jiriaie et al., 2013) and germination power (Salehzade et al., 2009; Gholamin and Khayatnezhad, 2010; Sayar et al., 2010; Tavares et al., 2012), to provide additional nutrients to seeds (Misra and Dwivedi, 1980; Paul and Choudhary, 1991), and to protect seeds from diseases (Tavares et al., 2012) and pests (Jibrin et al., 2013).

When the amount of precipitation is low and erratic, it is possible to delay germination by limiting the initial water intake of seeds. Seed coating can effectively reduce the water absorption (Schneider and Renualt, 1997) and delay their germination (Silva and Nakagawa, 1998; Stendahl, 2005). Glycerol and Aloe vera can be used as seed coatings to delay water absorption when ambient water levels are low and erratic. Glycerol (propanetriol) is a non-toxic trihydroxy organic alcohol that is liquid at room temperature. It is commonly used to increase the shelflife of industrially produced foods, both protecting foods from microorganisms and delaying their spoilage by reducing their intake of moisture (Shariatifar and Jafarpour, 2013).

Aloe vera (Aleo barbadensis) is a perennial droughtresistant succulent plant with fleshy leaves that belongs to the Asphodelaceae family. It is extensively used in the cosmetic (Aburjai et al., 2003) and pharmaceutical industries (Manvitha and Bidya, 2014). To date, no adverse health effects were associated with the use of Aloe vera. In recent years, it has been increasingly used to coat fruits and vegetables in order to increase their shelf-life (Alleyne and Hagenmaier, 2000; Tharanathan, 2003; Arowora et al., 2013; Athmaselvi et al., 2013). Using Aloe vera gel for coating in a manner similar to glycerol extends the shelf-life (Arowora et al., 2013) by reducing water loss and by protecting the product against microorganisms and fungal diseases (Jasso de Rodriguez et al., 2005).

The negative effects of global warming on precipitation in arid and semi-arid regions become more pronounced in recent years. In such regions, seed coating is being studied to understand how coating can prevent premature germination under conditions of irregular precipitation (i.e., the phenomenon known as "alatav," in which the soil is moist enough to trigger germination, but not sufficiently moist to ensure seed viability). In this study, the water absorption and the germination rates, and the viability duration after germination of bread wheat seeds that were coated with different concentrations of glycerol solution and Aloe vera were investigated following their exposure to four different levels of irrigation. The germination rates of the seeds following their second irrigation after 35 days were also evaluated.

\section{MATERIALS and METHODS}

Aloe vera gel was extracted from Aloe vera (Aleo barbadensis) leaves (Fig. 1). To increase its viscosity, the gel was pureed using a blender and mixed for five minutes with an agitator. Five different desired solutions containing $20 \%, 40 \%, 60 \%, 80 \%$, and $100 \%$ of Aloe vera were prepared by using distilled water. Each coating solution was prepared as a $200^{-} \mathrm{mL}$ solution. The five glycerol (propanetriol) coating solutions were prepared with the same methods used for Aloe vera solutions.

The 'Bayraktar' variety of bread wheat was used in the study. To prevent wheat seeds from rotting during germination, all seeds were treated with a fungicide 
prior to coated. The experiments were performed as six separate sets under similar conditions. Each set was subjected to four different irrigation levels and repeated three times each. Furthermore, each repeat was performed with both seed types of coatings (five doses of Aloe vera coating + one control, and five doses of glycerol coating + one control). In this study, 100 seeds were used for each coating and control group. To calculate the hourly water absorption rates, the 100 weight seeds from each of five sets was determined. Except for the control seeds, all seeds were immersed in an Aloe vera or glycerol solution, mixed for one minute, and removed from the solution. To prevent the seeds from sticking to each other following immersion in the coating solutions, the seeds were mixed with perlite dust to form pellets (Fig. 2). They were then dried for seven days at $27{ }^{\circ} \mathrm{C}\left( \pm 1{ }^{\circ} \mathrm{C}\right)$ under dark conditions. The controls were not coated.

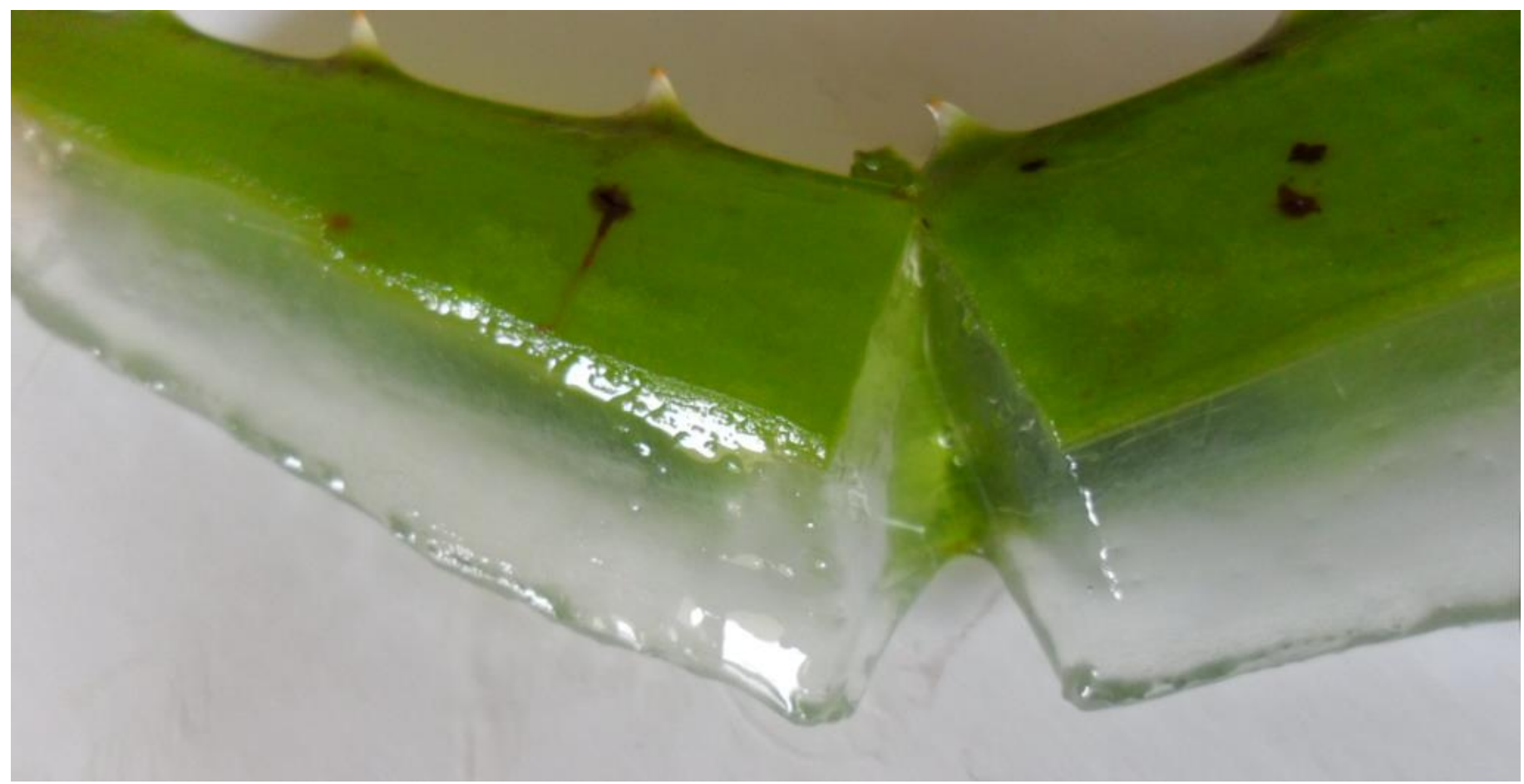

Figure 1. Gel in leaf of Aloe vera

Şekil 1. Aleo vera yaprăğında jel

Styrofoam containers with a base area of $78.5 \mathrm{~cm}^{2}$ and a height of $6 \mathrm{~cm}$ were used during the study. A quantity of $80 \mathrm{~g}$ of perlite was placed at the bottom of each container, and 100 coated or control seeds were uniformly planted into the perlite. In all sets, the first irrigation (IR1) was performed by adding $30,60,90$, or $120 \mathrm{~mL}$ of distilled water (1 kg of perlite retains $1.96 \mathrm{~L}$ of water in five minutes). The lids of the watered containers were closed to prevent evaporation, and the containers were kept in a climate chamber under controlled conditions for germination. The temperature of the climate chamber was $25^{\circ} \mathrm{C}\left( \pm 1^{\circ} \mathrm{C}\right)$, and humidity was 38\%. The climate chamber was kept entirely dark during the first five days of the experiment. From $6^{\text {th }}$ day of experiment, the chamber was arranged for 12 hours dark/light.

During the five days of dark, five of the six study sets were used to calculate the water absorption rates. The first set of seeds was removed from the perlite $1 \mathrm{~h}$ after watering (at time T1). These seeds were washed with tap water and dried using paper towels. The weight of 100 seeds (FW1) was then determined. Seeds from the other sets were similarly removed from perlite at 2,3 ,
4, and $5 \mathrm{~h}$ after irrigation (T2, T3, T4, and $\mathrm{T} 5$, respectively), and the same procedures were applied to them. The hourly water absorption rates of the coated and control seeds were calculated using the formula that follows (Eq. 1).

$$
W U_{T j}=\frac{(F W j-I W j)}{F W j} 100
$$

where $W U$ - water uptake (\%), $\mathrm{Tj}$ - trait per hour of sample, $F W$ - final weight of sample (g), $I W$ - initial weight of sample (g), and j- hour.

The sixth set of seeds was used to calculate the germination rates. On the fifth day of the experiment, the number of coated and control seeds in the sixth set that germinated were counted without removing the seeds. The containers from which these germinated seeds had been counted were then returned to the climate chamber at $27^{\circ} \mathrm{C}\left( \pm 1{ }^{\circ} \mathrm{C}\right)$ and $38 \%$ humidity and the lids were left open. The time between the day of planting and dying of the seeds (due to lack of water) was considered the viability duration (VD). 


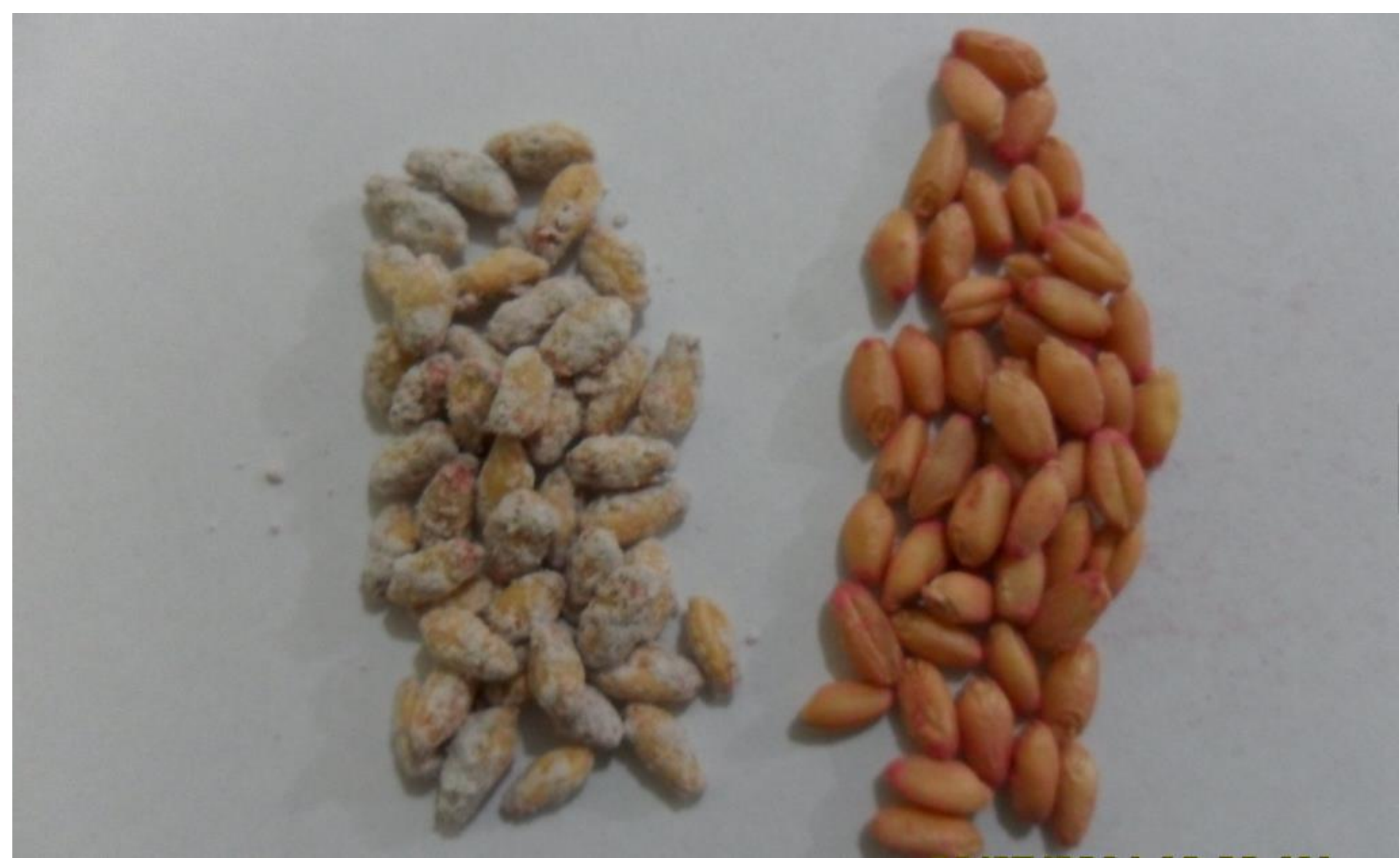

Figure 2. Coated seeds with Aloe vera (100\%) (on the right), uncoated (control) seeds (on the left). Shekil 2. Sağda Aleo vera ile kaplanmış (\%100) tohumlar ve solda kaplanmamıss tohumlar (Kontrol)

To determine the daily rate of evaporation, separate containers containing perlite without seeds were also prepared. These containers were watered with 30,60 , 90 , and $120 \mathrm{~mL}$ of distilled water and weighed daily. The weighing procedure was repeated until the dry weight of the perlite was obtained. The daily evaporation rates of water from the perlite from all four containers (watered with 30,60, 90, and $120 \mathrm{~mL}$ of distilled water) are shown in Figure 3. For the container that received $30 \mathrm{~mL}$ of distilled water, complete evaporation occurred by day 9. For the containers that received 60,90 , and $120 \mathrm{~mL}$, complete evaporation occurred by days 20, 24, and 29, respectively.

On day 35, all of the dried coated and control seeds received a second irrigation (IR2) with $150 \mathrm{~mL}$ of distilled water. The number of germinated seeds was determined on the fifth day following IR2. As each container had 100 seeds initially, the number of germinated seeds was provided in the results and discussion section as a percentage.

The collected data were statistically analyzed using the SAS (1988) as Complete Randomized Factorial Design. In cases where the F-test indicated statistical significance $(p<0.05)$, means were compared by the Least Significant Difference test.

\section{RESULTS and DISCUSSION}

All of the evaluated characteristics were affected by the type of coating, the solution ratios, the amount of irrigation, and the interactions among these parameters $(p<0.01)$. At $1,2,3,4$, and $5 \mathrm{~h}$ following irrigation, the seeds coated with Aloe vera solution exhibited higher levels of water absorption than those of glycerol solutions (Table 1). At $\mathrm{T} 1$ ( $1 \mathrm{~h}$ after irrigation), the Aloe vera-coated seeds exhibited 47.2\% higher water absorption than glycerol-coated seeds. However, the difference between the levels of water absorption gradually decreased over time. At T2, T3, $\mathrm{T} 4$, and $\mathrm{T} 5$, the Aloe vera-coated seeds exhibited $43.5 \%, \quad 35.6 \%, 29.7 \%$, and $29.3 \%$ higher water absorption than the glycerol-coated seeds. After IR1, the Aloe vera-coated seeds exhibited $17.4 \%$ greater germination than the glycerol-coated seeds, while after the second irrigation IR2 the Aloe vera-coated seeds exhibited $42.9 \%$ greater germination than the glycerolcoated seeds.

Depending on the solution concentrations and comparisons, with the control seeds, significant differences were observed among the coated seeds with respect to the seed characteristics $(p<0.01)$. At all times following the first irrigation, the highest rate of water absorption was observed in the control seeds (Table 1). The water absorption rate of the control seeds was $22.02 \%$ at $\mathrm{T} 1$ and $60.69 \%$ at $\mathrm{T} 5$. Among the 
different solution ratios, the highest water absorption rate was observed for the $20 \%$ of Aloe vera solution.

The water absorption rate of the seeds gradually decreased as the concentration of the Aloe vera solution increased to $40 \%, 60 \%, 80 \%$, and $100 \%$. At IR 1 , the control seeds sustained a germination rate of $99.75 \%$, while the seeds treated with $100 \%$ Aloe vera solution had the lowest germination rate. On the other hand, none of the control seeds exhibited any germination following IR2, because all of the control seeds germinated at all of the irrigation levels at IR1. The lowest germination rate was observed for the $20 \%$ of Aloe vera solution (6.5\%), while the $100 \%$ of Aloe vera solution sustained the highest germination (50.79\%). A negative relationship was observed between the solution concentrations and the germination rates at IR1 $\left(r=-0.981^{* *}\right)$. Meanwhile, there was a positive relationship between the solution concentrations and the germination rates at IR2 $(\mathrm{r}=-$ $0.980 * *)$. As expected, significant differences were apparent between the data collected at different times for different levels of irrigation (Table 1). At IR1, the VD of the glycerol-coated seeds was higher (3\%) than that of Aloe vera-coated seeds. In addition, an increase in coating concentrations and irrigation levels was associated with an increase in VD values.

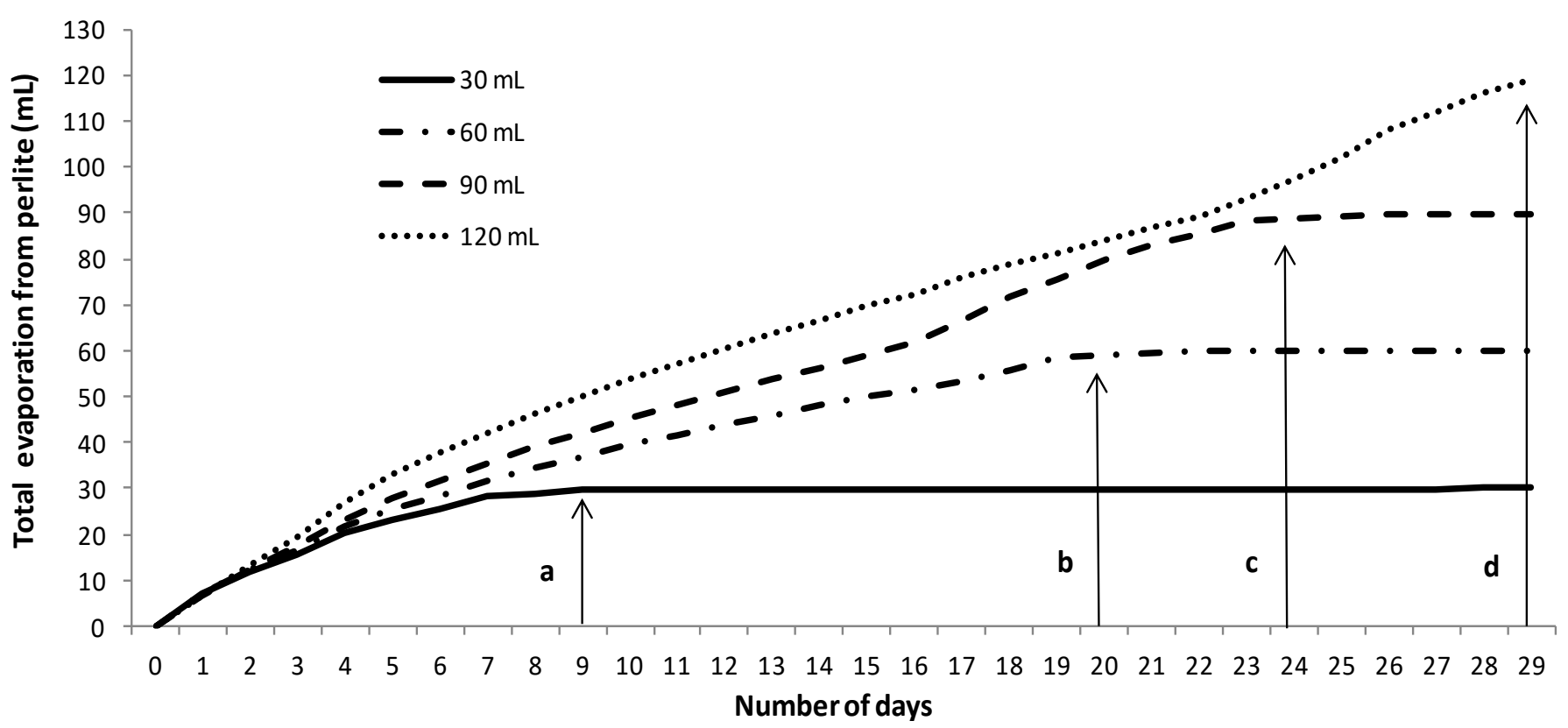

Figure 3. Daily evaporation of containers with perlite without seeds. Complete evaporation formed (a) by day 9 from the container that received $30 \mathrm{~mL}$ of water, (b) by day 20 from the container that received $60 \mathrm{~mL}$ of water, (c) by day 24 from the container that received $90 \mathrm{~mL}$ of water, and (d) by day 29 from the container that received $120 \mathrm{~mL}$ of water.

Şekil 3. Perlitli fakat tohumsuz kaplardan günlük buharlaşma. Tam buharlaşma (a) 9. günde $30 \mathrm{~mL}$ su alan kaptan, (b) 20. günde $60 \mathrm{~mL}$ su alan kaptan, (c) 24. günde $90 \mathrm{~mL}$ alan kaptan gerçekleşti. ve (d) 29. güne kadar $120 \mathrm{~mL}$ su alan kaptan gerçekleşti.

At IR1, the highest water absorption rate for all solution ratios was observed for an irrigation amount of $120 \mathrm{~mL}$. At all irrigation levels, the control seeds displayed the highest water absorption rates. The seeds that demonstrated the next highest rate of water absorption were the 20\% Aloe vera- and glycerolcoated seeds. At an irrigation level of $30 \mathrm{~mL}$, seeds coated with any concentration of glycerol solution absorbed less water than seeds covered with an equal concentration of Aloe vera solution. At an irrigation level of $30 \mathrm{~mL}$, seeds coated with $100 \%$ glycerol solution absorbed $61.8 \%$ less water at T5 than seeds covered with the $100 \%$ Aloe vera solution. A similar difference in water absorption rates was observed for other concentrations of Aloe vera and glycerol.
On the fifth day following IR1, the germination rates of the control seeds and of the Aloe vera and glycerolcoated seeds increased parallel to their water absorption rates $\left(r=0.316^{* *}\right)$. As expected, the highest level of germination during IR1 was observed at an irrigation level of $120 \mathrm{~mL}$ (Fig. 4). As the level of irrigation decreased from $120 \mathrm{~mL}$ to $30 \mathrm{~mL}$, a parallel decrease was observed in the germination rate. At IR1, all of the control seeds germinated at all of the irrigation levels. At various levels of irrigation, seeds coated with the glycerol solution exhibited lower germination rates than seeds coated with the Aloe vera solution. At an irrigation level of $30 \mathrm{~mL}, 17 \%$ of the seeds coated with $100 \%$ Aloe vera germinated, while none of those coated with $100 \%$ glycerol did (Fig. 4). 
Table 1. Mean values for the water absorption of seeds in the first five hours (T1, T2, T3, T4, and T5), the viability duration (VD), and the germination rate at the first and second irrigations (IR1 and IR2) according to coating type, coating solution concentration, and irrigation amount.

Tablo 1. Ilk beş saat içinde tohumların su emmesi için ortalama değerler (T1, T2, T3, T4 ve T5), canlılık süresi (VD) ve kaplama tipine göre birinci ve ikinci sulamalarda (IR1 ve IR2) çimlenme oranı, kaplama çözeltisi konsantrasyonu ve sulama miktarı.

\begin{tabular}{|c|c|c|c|c|c|c|c|c|}
\hline \multirow[t]{2}{*}{ Variable (Değişken) } & \multicolumn{5}{|c|}{$\begin{array}{c}\text { Hours after first irrigation } \\
\text { (Ilk Sulamadan Sonraki Saatler) }\end{array}$} & \multirow{2}{*}{$\begin{array}{l}\text { IR1 } \\
(\%) \\
\end{array}$} & \multirow{2}{*}{$\frac{\text { VD }}{\text { (days) }}$} & \multirow{2}{*}{$\begin{array}{l}\text { IR2 } \\
(\%)\end{array}$} \\
\hline & $\mathrm{T} 1$ & $\mathrm{~T} 2$ & T3 & $\mathrm{T} 4$ & T5 & & & \\
\hline $\begin{array}{l}\text { Coating type }(\mathrm{C}) \\
\text { (Kaplama Sekli) }\end{array}$ & $* *$ & $* *$ & $* *$ & $* *$ & $* *$ & $* *$ & $*$ & $* *$ \\
\hline Aloe vera & 14.76 & 24.79 & 30.27 & 35.77 & 42.11 & 82.97 & 18.45 & 15.44 \\
\hline Glycerol & 10.03 & 17.27 & 22.33 & 27.58 & 32.57 & 70.68 & 19.01 & 27.07 \\
\hline Mean (Ortalama) & 12.40 & 21.03 & 26.30 & 31.67 & 37.34 & 76.83 & 18.73 & 21.26 \\
\hline LSD $\S(0.05)$ & 0.09 & 0.06 & 0.09 & 0.20 & 0.21 & 1.29 & 0.43 & 1.35 \\
\hline $\begin{array}{l}\text { Coating solution concentration (S) } \\
\text { (Kaplama Cözeltisinin Konsantrasyonu) }\end{array}$ & $* *$ & $* *$ & $* *$ & $* *$ & $* *$ & $* *$ & $* *$ & $* *$ \\
\hline $0 \%$ & 22.02 & 40.33 & 47.11 & 54.91 & 60.69 & 99.75 & 17.75 & 0.00 \\
\hline $20 \%$ & 15.30 & 26.44 & 30.82 & 36.89 & 42.09 & 90.58 & 17.88 & 6.50 \\
\hline $40 \%$ & 13.70 & 23.57 & 27.96 & 33.08 & 38.79 & 85.21 & 18.54 & 13.29 \\
\hline $60 \%$ & 11.31 & 19.03 & 22.74 & 27.84 & 32.61 & 76.96 & 18.90 & 20.96 \\
\hline $80 \%$ & 7.24 & 10.09 & 15.79 & 20.13 & 27.46 & 62.04 & 19.50 & 36.00 \\
\hline $100 \%$ & 4.80 & 6.75 & 13.38 & 17.18 & 22.41 & 46.42 & 19.81 & 50.79 \\
\hline LSD (0.05) & 0.16 & 0.11 & 0.16 & 0.34 & 0.35 & 2.23 & 1.05 & 2.33 \\
\hline $\begin{array}{l}\text { Irrigation amount (I) } \\
\text { (Sulama Toplamı) }\end{array}$ & $* *$ & $* *$ & $* *$ & $* *$ & $* *$ & $* *$ & $* *$ & $* *$ \\
\hline $30 \mathrm{~mL}$ & 9.26 & 17.08 & 22.29 & 27.08 & 31.12 & 49.53 & 9.07 & 47.06 \\
\hline $60 \mathrm{~mL}$ & 10.61 & 20.01 & 24.99 & 30.85 & 35.41 & 72.81 & 16.71 & 25.33 \\
\hline $90 \mathrm{~mL}$ & 14.16 & 22.87 & 28.19 & 33.62 & 40.00 & 87.97 & 22.44 & 10.61 \\
\hline $120 \mathrm{~mL}$ & 15.55 & 24.18 & 29.73 & 35.14 & 42.83 & 97.00 & 26.72 & 2.03 \\
\hline $\operatorname{LSD}(0.05)$ & 0.13 & 0.09 & 0.13 & 0.28 & 0.29 & 1.98 & 0.81 & 1.90 \\
\hline \multicolumn{9}{|l|}{ Interaction (Interaksiyon) } \\
\hline $\mathrm{C} \times \mathrm{S}$ & $* *$ & $* *$ & $* *$ & $* *$ & $* *$ & $* *$ & $* *$ & $* *$ \\
\hline $\mathrm{C} \times \mathrm{I}$ & $* *$ & $* *$ & $* *$ & $* *$ & $* *$ & $* *$ & $* *$ & $* *$ \\
\hline S x I & $* *$ & $* *$ & $* *$ & $* *$ & $* *$ & $* *$ & $* *$ & $* *$ \\
\hline $\mathrm{C} \times \mathrm{S} \times \mathrm{I}$ & $* *$ & $* *$ & $* *$ & $* *$ & $* *$ & $* *$ & $* *$ & $* *$ \\
\hline CV (\%) & 2.23 & 0.87 & 1.06 & 1.89 & 1.65 & 5.07 & 1.94 & 4.07 \\
\hline
\end{tabular}

$\S:$ least significant difference test

** : highly significant $(p<0.01)$

This difference in germination rates was due to the lower water absorption of glycerol-coated seeds in comparison with the control and Aloe vera-coated seeds (Table 2). A previous study reported that coating safflower plant seeds with acrylic plastic polymers reduced germination on the fifth day by at least $5 \%$ (Dizaj, 2010). Similar results regarding the germination delaying effect of different seed coatings were reported by Silva and Nakagawa (1998), and Stendahl (2005).

Glycerol-coated seeds generally demonstrated higher VD values than did control and the Aloe vera-coated seeds, the only exceptions being the $20 \%$ glycerolcoated seeds at all irrigation levels, and the 100\% glycerol-coated seeds at an irrigation level of $30 \mathrm{~mL}$. The VD values of the Aloe vera-coated seeds were between the values observed for the glycerol-coated seeds and the control seeds. As the seeds coated with $100 \%$ glycerol solution exhibited no germination at an irrigation level of $30 \mathrm{~mL}$, the $\mathrm{VD}$ value for these seeds was zero. At an irrigation level of $120 \mathrm{~mL}$, the VD value of $100 \%$ glycerol-coated seeds was $3.7 \%$ higher than that of the $100 \%$ Aloe vera-coated seeds and $7.7 \%$ higher than that of the control seeds.As shown in 
Figure 5, both the control seeds and the coated seeds had lower VD values than the number of days necessary for complete evaporation from unplanted containers (Fig. 3).

Table 2. The effects of four different irrigation levels and of different coating solution concentrations on the water absorption of seeds during the first 5 hours (T1, T2, T3, T4, and T5).

Tablo 2. Dört farklı sulama seviyesinin ve farklı kaplama çözeltisi konsantrasyonlarının, ilk 5 saatte (T1, T2, T3, T4 ve T5) tohumların su emmesi üzerindeki etkileri.

\begin{tabular}{|c|c|c|c|c|c|c|c|}
\hline \multirow{2}{*}{$\begin{array}{l}\text { Irrigation amount }(\mathrm{mL}) \\
\text { (Sulama Toplamı) }\end{array}$} & \multirow{2}{*}{ 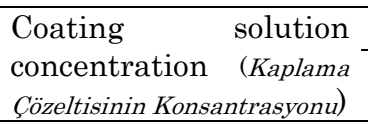 } & \multicolumn{5}{|c|}{ Water absorption (\%) (Su Alımı) } & \multirow[b]{2}{*}{ Mean } \\
\hline & & $\mathrm{T} 1$ & $\mathrm{~T} 2$ & $\mathrm{~T} 3$ & $\mathrm{~T} 4$ & T5 & \\
\hline \multirow[t]{11}{*}{30} & AL $100 \%$ & 4.67 & 7.03 & 15.44 & 21.52 & 23.96 & 14.52 \\
\hline & AL 80\% & 6.99 & 10.80 & 18.18 & 24.32 & 29.01 & 17.86 \\
\hline & AL 60\% & 9.76 & 23.3 & 27.54 & 31.51 & 33.21 & 25.06 \\
\hline & AL $40 \%$ & 12.76 & 25.58 & 29.55 & 33.43 & 37.37 & 27.74 \\
\hline & AL $20 \%$ & 14.98 & 27.74 & 30.91 & 37.56 & 43.41 & 30.92 \\
\hline & GL 100\% & 1.76 & 2.55 & 5.16 & 7.63 & 9.15 & 5.25 \\
\hline & GL 80\% & 2.58 & 3.31 & 6.95 & 9.37 & 14.85 & 7.41 \\
\hline & GL 60\% & 4.72 & 8.32 & 12.30 & 18.2 & 23.70 & 13.45 \\
\hline & GL 40\% & 7.51 & 16.74 & 22.89 & 28.08 & 33.20 & 21.68 \\
\hline & GL $20 \%$ & 8.86 & 20.84 & 25.29 & 31.02 & 35.1 & 24.22 \\
\hline & 0 & 18.24 & 29.34 & 36.64 & 41.16 & 45.23 & 34.12 \\
\hline \multirow[t]{11}{*}{60} & AL $100 \%$ & 6.15 & 9.23 & 17.67 & 23.13 & 26.04 & 16.44 \\
\hline & AL 80\% & 8.12 & 11.83 & 20.35 & 25.76 & 30.61 & 19.33 \\
\hline & AL 60\% & 12.50 & 26.32 & 28.66 & 32.00 & 34.11 & 26.72 \\
\hline & AL $40 \%$ & 13.19 & 27.64 & 30.49 & 34.24 & 39.41 & 28.99 \\
\hline & AL $20 \%$ & 17.31 & 29.43 & 34.01 & 39.46 & 45.02 & 33.05 \\
\hline & GL 100\% & 2.06 & 2.97 & 6.15 & 8.12 & 10.85 & 6.03 \\
\hline & GL 80\% & 2.84 & 3.44 & 8.60 & 10.19 & 17.45 & 8.50 \\
\hline & GL 60\% & 6.50 & 8.59 & 13.90 & 20.80 & 24.47 & 14.85 \\
\hline & GL $40 \%$ & 7.97 & 18.84 & 24.28 & 30.71 & 34.01 & 23.16 \\
\hline & GL 20\% & 9.46 & 21.75 & 26.56 & 31.38 & 37.55 & 25.34 \\
\hline & 0 & 20.60 & 40.03 & 44.59 & 57.20 & 62.71 & 45.03 \\
\hline \multirow[t]{11}{*}{90} & AL 100\% & 8.64 & 10.98 & 20.25 & 25.51 & 37.36 & 20.55 \\
\hline & AL 80\% & 12.93 & 14.23 & 23.20 & 28.72 & 38.39 & 23.49 \\
\hline & AL $60 \%$ & 14.61 & 27.63 & 29.9 & 33.80 & 39.62 & 29.11 \\
\hline & AL $40 \%$ & 18.30 & 29.60 & 32.03 & 35.43 & 40.83 & 31.24 \\
\hline & AL $20 \%$ & 20.12 & 32.04 & 34.27 & 41.95 & 45.42 & 34.76 \\
\hline & GL 100\% & 2.44 & 3.43 & 9.86 & 11.47 & 14.61 & 8.36 \\
\hline & GL 80\% & 4.10 & 9.43 & 12.75 & 16.50 & 22.29 & 13.01 \\
\hline & GL 60\% & 10.04 & 14.72 & 18.74 & 26.18 & 30.11 & 19.96 \\
\hline & GL 40\% & 14.99 & 19.83 & 24.91 & 32.81 & 38.69 & 26.25 \\
\hline & GL 20\% & 15.50 & 23.38 & 28.26 & 33.80 & 39.93 & 28.17 \\
\hline & 0 & 24.13 & 44.59 & 52.04 & 58.60 & 66.38 & 49.15 \\
\hline \multirow[t]{11}{*}{120} & AL 100\% & 9.72 & 12.58 & 22.23 & 27.53 & 40.50 & 22.51 \\
\hline & AL $80 \%$ & 15.66 & 17.56 & 23.36 & 29.38 & 43.34 & 25.86 \\
\hline & AL 60\% & 19.86 & 27.72 & 31.21 & 33.95 & 44.56 & 31.46 \\
\hline & AL $40 \%$ & 19.56 & 29.67 & 32.20 & 36.86 & 46.87 & 33.03 \\
\hline & AL $20 \%$ & 20.26 & 32.88 & 36.66 & 42.66 & 48.82 & 36.26 \\
\hline & GL 100\% & 2.97 & 5.26 & 10.25 & 12.54 & 16.79 & 9.56 \\
\hline & GL 80\% & 4.66 & 10.14 & 13.00 & 16.76 & 23.72 & 13.66 \\
\hline & GL 60\% & 12.47 & 15.59 & 19.68 & 26.25 & 31.12 & 21.02 \\
\hline & GL $40 \%$ & 15.33 & 20.63 & 27.33 & 33.10 & 39.94 & 27.27 \\
\hline & GL $20 \%$ & 15.91 & 23.46 & 30.61 & 37.27 & 41.44 & 29.74 \\
\hline & 0 & 25.11 & 47.35 & 55.17 & 62.70 & 68.43 & 51.75 \\
\hline Mean (Ortalama) & & 11.52 & 19.28 & 24.41 & 29.56 & 35.22 & \\
\hline LSD (0.05) & & 0.47 & 0.29 & 0.42 & 0.88 & 0.91 & \\
\hline
\end{tabular}

$\mathrm{AL}$ - Aloe vera; GL - glycerol; 0 - control 


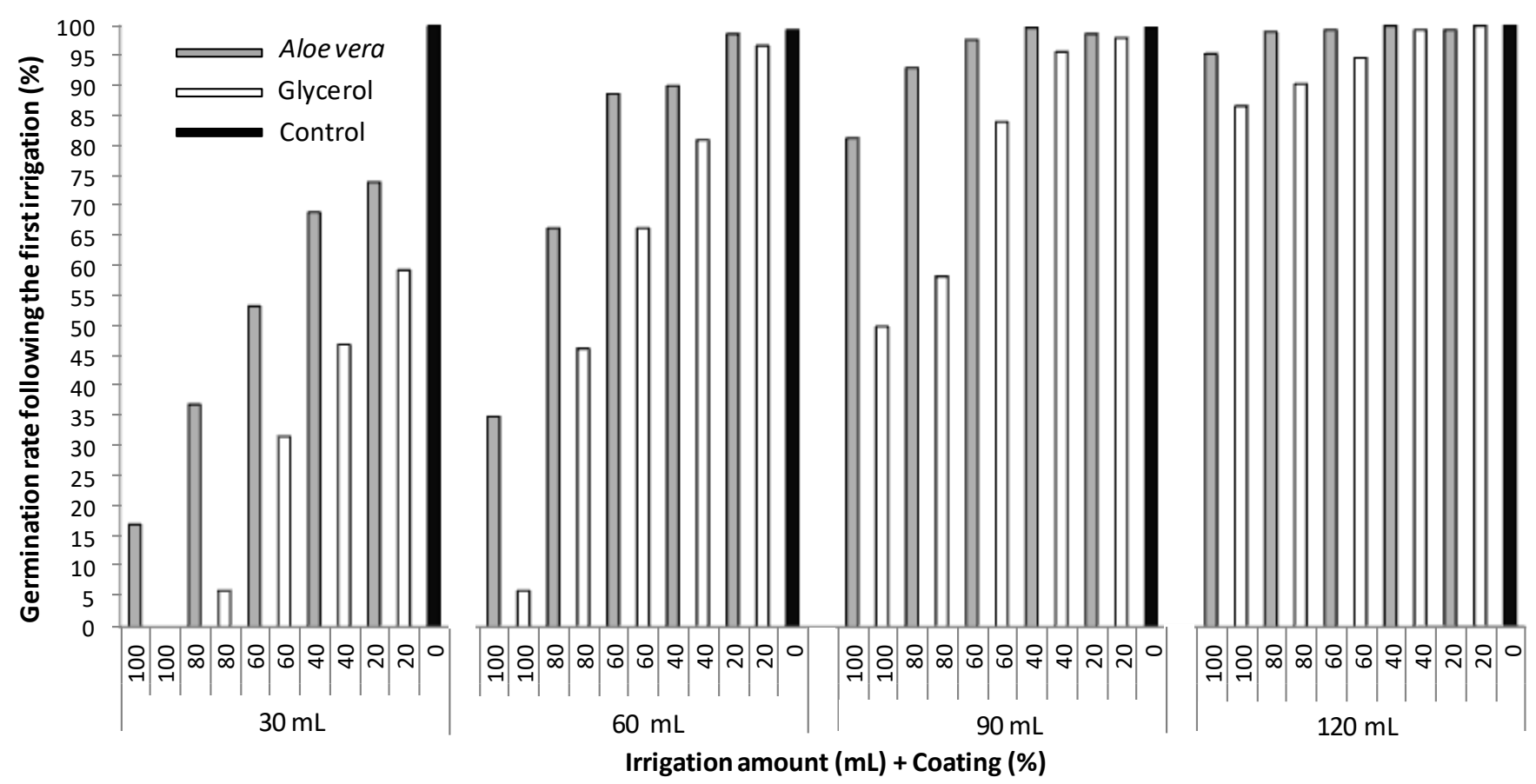

Figure 4. The effect of the first irrigation levels $(30,60,90$, and $120 \mathrm{~mL})$ and coating concentrations $(0 \%, 20 \%, 40 \%$, $60 \%, 80 \%$, and $100 \%)$ on the seed germination rates $(\%)$.

Şekil 4. Buğday tohumlarının çimlenme oranları (\%) üzerine ilk sulama miktarlarının (30, 60, 90 ve $120 \mathrm{~mL}$ ) ve kaplama konsantrasyonlarının (\%0, \%20, \%40, \%60, \%80 ve \%100) etkisi.

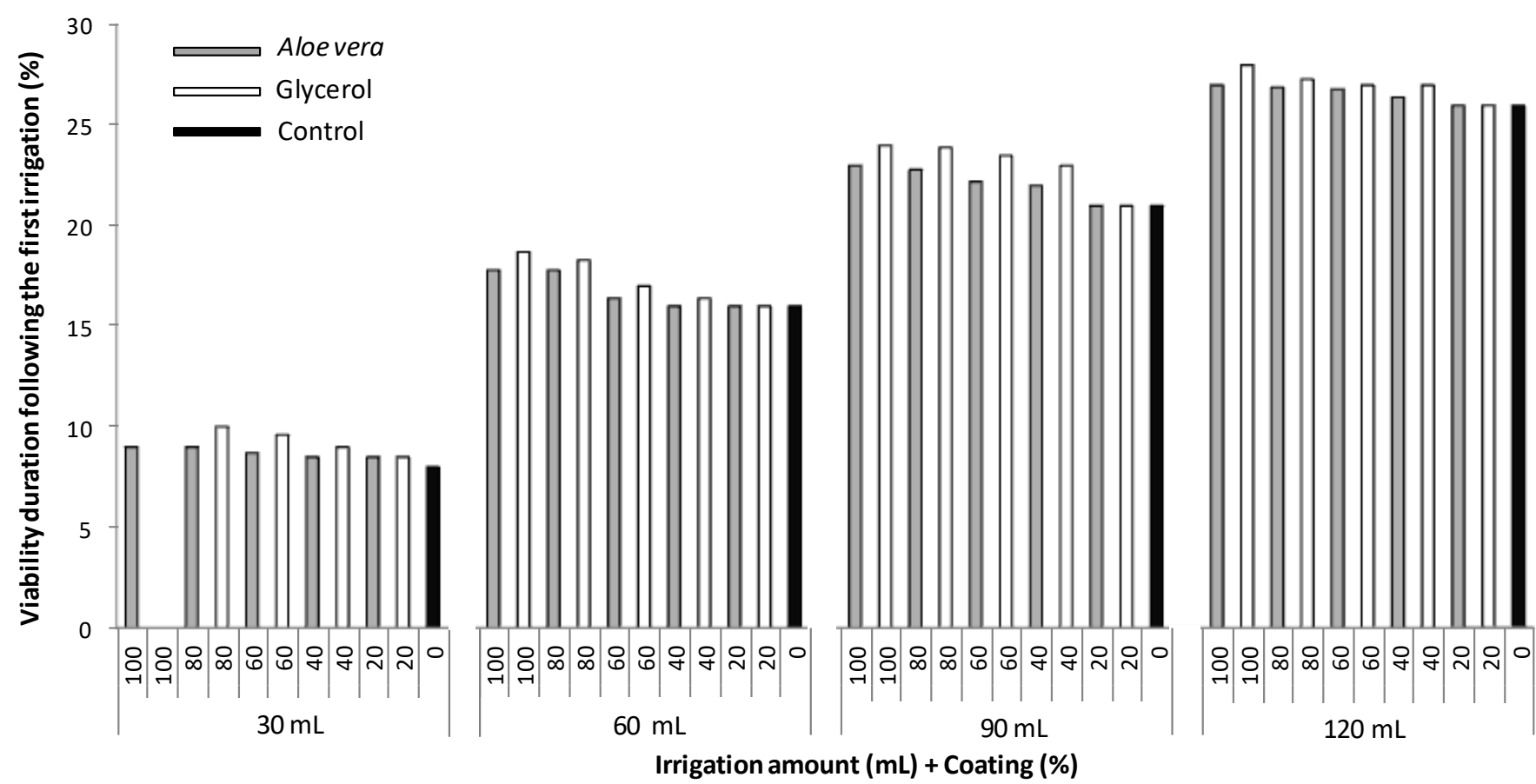

Figure 5 . The effect of the first irrigation levels $(30,60,90$, and $120 \mathrm{~mL})$ and coating concentrations $(0 \%, 20 \%, 40 \%$, $60 \%, 80 \%$, and $100 \%$ ) on the viability duration (days) of germinated seeds (Note: No germination was observed of $100 \%$ glycerol-coated seeds that received $30 \mathrm{~mL}$ of water for the first irrigation).

Şekil 5. Ilk sulama miktarlarının (30, 60, 90 ve $120 \mathrm{~mL}$ ) ve kaplama konsantrasyonlarının (\%0, \%20, \%40, \%60, $\% 80$ ve \%100) çimlenmiş tohumların canlllık süresi (gün) üzerindeki etkisi (Not: Illk sulama için $30 \mathrm{~mL}$ su alan \%100 gliserol kaplı tohumlarda çimlenme gözlenmemiştir). 
This result is due to the fact that water is lost from the unplanted containers only through evaporation, while it is lost from the planted containers via evaporation, respiration, and photosynthesis. For this reason, less time was necessary for the perlite to dry out completely from the planted containers, causing the plants to have lower VD values. The results of this study are in agreement with the findings of Corlett et al. (2014), who observed that coated barley seeds were viable after germination for a longer period of time than were control seeds.

After IR2, a negative relationship was observed between germination rates and the water absorption rates of control, Aloe vera-coated, and glycerol-coated seeds $(r=0.309 * *)$. The germination rates at IR2 (which represent the final parameter of the study) were drastically different from the germination rates obtained at IR1 $\left(r=-0.998^{* *}\right)$ (Fig. 6). This result was found because the seeds that germinated at IR1 had completely dried and died by day 25; these seeds were thus not able to germinate at IR2 (Fig. 2). Except for the control seeds, all seeds coated with solutions of different concentrations were able to germinate at IR2 at an irrigation level of $30 \mathrm{~mL}$. At an irrigation level of $30 \mathrm{~mL}$, the highest germination rates were observed among the $100 \%$ and $80 \%$ glycerol-coated seeds $(96 \%$ and $90.67 \%$, respectively). Seeds coated with the $100 \%$ Aloe vera solution, on the other hand, had a germination rate of $79 \%$. At an irrigation level of 60 $\mathrm{mL}$, the highest germination rate was observed with the $100 \%$ glycerol-coated seeds (92.33\%). At an irrigation level of $120 \mathrm{~mL}$ during IR2, only the $60 \%$, $80 \%$, and $100 \%$ glycerol-coated seeds and the $100 \%$ Aloe vera-coated seeds showed any germination
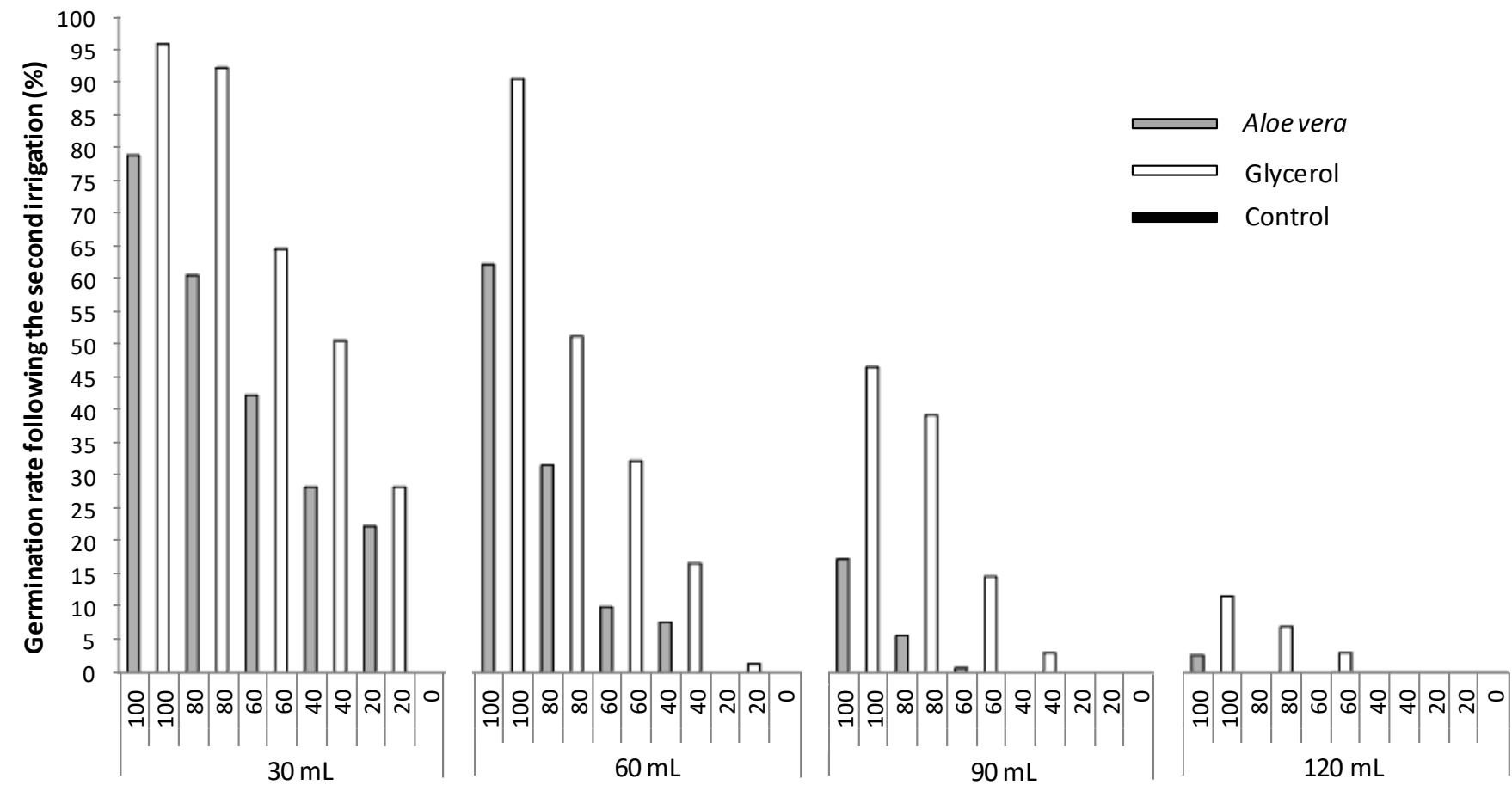

Irrigation amount $(\mathrm{mL})+$ Coating (\%)

Figure 6. The effect of the first irrigation levels (30, 60, 90, and $120 \mathrm{~mL})$ and coating concentrations (0\%, 20\%, 40\%, $60 \%, 80 \%$, and $100 \%)$ on seed germination rates following the second irrigation $(120 \mathrm{~mL})$.

Şekil 6. Ilk sulama miktarlarının (30, 60, 90 ve $120 \mathrm{~mL}$ ) ve kaplama konsantrasyonlarının (\%0, \%20, \%40, \%60, $\% 80$ ve \%100) ikinci sulamadan sonra $(120 \mathrm{~mL})$ buğday tohumlarının çimlenme oranları üzerindeki etkisi.

\section{CONCLUSIONS}

1. In this study, the seeds coated with different concentrations of Aloe vera and glycerol significantly differed from the control seeds with respect to all of the characteristics evaluated. In all the seeds, an increase in water absorption was associated with an increase in germination rates. In the hours following initial irrigation, seeds coated with the glycerol solution absorbed less water than those of coated with the Aloe vera solution, indicating that glycerol had lower water permeability than Aloe vera.

2. At IR1, all of the control seeds germinated at all of the irrigation levels. For this reason, none of the control seeds germinated at IR2. A decrease in the coating concentrations of Aloe vera and glycerol was 
associated with a higher level of germination at IR1 and thus a lower level of germination at IR2. At IR1 and with an irrigation level of $30 \mathrm{~mL}$, no germination was observed in the $100 \%$ glycerolcoated seeds. After IR2, 96\% of these seeds germinated. Evidently, glycerol prevented the seeds from absorbing water at the lowest irrigation level used during the study $(30 \mathrm{~mL})$.

3. At all irrigation levels used during IR1, the glycerolcoated seeds remained viable for longer periods after irrigation than the Aloe vera-coated seeds and control seeds.

4. The results indicated that the risk of early germination associated with low and erratic precipitation under arid and semi-arid field conditions may be effectively eliminated for wheat seeds by using seed coatings. It would be beneficial to conduct more complex studies with different concentrations of Aloe vera and glycerol solutions, in order to further investigate the applicability of seed coatings in experiments conducted under field conditions.

\section{Conflict of interest statement}

There are no conflicts to declare.

\section{REFERENCES}

Abdoli M, Saeidi M 2012. Effects of Water Deficiency Stress During Seed Growth on Yield and Its Components, Germination and Seedling Growth Parameters of Some Wheat Cultivars. International Journal of Agriculture and Crop Sciences 4: 1110-1118.

Aburjai T, Natsheh FM 2003. Plants Used in Cosmetics. Phytother Research 17: 987-1000.

Alleyne V, Hagenmaier RD 2000. Candelilla-shellac: an Alternative Formulation for Coating Apples. Horti Science 35: 691-693.

Almaghrabi OA 2012. Impact of Drought Stress on Germination and Seedling Growth Parameters of Some Wheat Cultivars. Life Science Jjournal 9: 590-598.

Arowora KA, Williams JO, Adetunji CO, Fawole OB, Afolayan SS, Olaleye OO, Adetunji JB, Ogundele BA 2013. Effects of Aloe vera Coatings on Quality Characteristics of Oranges Stored Under Cold Storage. Greener Journal of Agricultural Science 3: 39-47.

Athmaselvi KA, Sumitha P, Revathy B 2013. Development of Aloe vera Based Edible Coating for Tomato. International Agrophys 27: 369-375.

Corlett FMF, Rufino CA, Vieira JF, Tavares LC, Tunes LVM, Barros ACSA 2014. The İnfluence of Seed Coating on The Vigor and Early Seedling Growth of Barley. Ciencia Invevtigasion Agraria 41(1): 129136.
Dizaj KA 2010. Seed Coating of Safflower (Carthamus tinctorius L.) in Order to Delay Germination. African Journal of Plant Science 4: 267-269.

Eskandari H 2013. Effects of Priming Technique on Seed Germination Properties, Emergence and Field Performance of Crops: A review. International Journal Agronomy and Plant Production 4: 454458.

Gholamin R, Khayatnezhad M 2010. Effects of Polyethylene Glycol and $\mathrm{NaCl}$ Stress on Two Cultivars of Wheat (Triticum durum) at Germination and Early Seedling Stages. AmericanEurasian Journal of Agriculture and Environmental Sciences 9: 86-90.

Jasso de Rodríguez D, Hernández-Castillo D, Rodríguez-Garcia R, Angulo-Sánchez JL 2005. Antifungal Activity in Vitro of Aloe Vera Pulp and Liquid Fraction Against Plant Pathogenic Fungi. Industrial Crops and Products 21(1): 81-87.

Jibrin DM, Abdullah J, Ibrahim U 2013. Evaluation of Some Plant Products for The Control of The Cowpea Weevil (Callosobruchus maculatus). AmericanEurasian Journal of Agriculture and Environmental Sciences 13: 673-676.

Jiriaie M, Fateh E, Shahbazi S, Jashni R 2013. Effect of Salicylic Acid and Seed Weight on Germination of Wheat (Cv. Bc Roshan) under Different Levels of Osmotic Stress. World Applie Science Journal 28: 1825-1830.

Khayatnezhad M, Gholamin R, Jamaati-e-Somarin S, Zabihi-e-Mahmoodabad R 2010. Study of Water Stress Effect on Wheat Genotypes on Germination Indexes. Middle-East Journal of Scientific Research 6: 657-660.

Kulkarni M, Deshpande U 2007. In vitro Screening of Tomato Genotypes for Drought Resistance Using Polyethylene Glycol. African Journal of Biotechnology 6: 691-696.

Liu LH, Zabaras D, Bennett LE, Aguas P, Woonton BW 2009. Effects of UV-C, Red Light and Sun Light on The Carotenoid Content and Physical Qualities of Tomatoes During Post-Harvest Storage. Food Chemistry 115: 495-500.

Manvitha K, Bidya B 2014. Aloe vera: A Wonder Plant Its History, Cultivation and Medicinal Uses. Ournal of Pharmacognosy and Phytochemistry 2: $85-88$.

Mathre DE, Johnston RH 1991. Control of Dry Seed Decay of Wheat. Plant Diseases 75: 957-959.

Misra NM, Dwivedi DP 1980. Effect of Pre-Sowing Seed Treatments on Growth and Dry-Matter Accumulation of High-Yielding Wheats under Rainfed Conditions. Indian Journal of Agronomy 25: 230-234.

Paul SR, Choudhary AK 1991. Effect of Seed Priming with Salts on Growth and Yield of Wheat under Rain Fed Conditions. Ann Agricultural Research 12: 415-418. 
Salehzade H, Shishvan MI, Ghiyasi M, Forouzin F, Siyahjani AA 2009. Effect of Seed Priming on Germination and Seedling Growth of Wheat (Triticum aestivum L.). Research Journal of Biological Sciences 45: 629-631.

Sayar R, Bchini H, Mosbahi M, Khemira H 2010. Response of Durum Wheat (Triticum durum Desf.) Growth to Salt and Drought Stresses. Czech Journal of Genetics and Plant Breeding 46: 54-63.

Schneider A, Renualt P 1997. Effects of Coating on Seed Imbibition: II. Effect of Coating Rates. Crop Science 37: 1850-1857.

Shariatifar M, Jafarpour E 2013. Edible Coating Effects on Storage Life and Quality of Apple. Journal of Basic and Applied Science Research 3: 24-27.

Silva JBC, Nakagawa J 1998. Confecção e Avaliação De Péletes De Sementes De Alface. Horticultura Brasileira 16: 151-158.
Stendahl F 2005. Seed coating for delayed germination: A Tool for Relay Cropping of Annual Crops. PhD Thesis, Swedish University of Agricultural Sciences, Uppsala, Sweden.

Tavares LC, Rufino CA, Dorr CS, Barros ASCA, Peske ST 2012. Performance of Lowland Rice Seeds Coated with Dolomitic Limestone and Aluminum Silicate. Revista Brasileira de Sementes, 34: 202211.

Tharanathan RN 2003. Biodegradable Films and Composite Coatings: Past, Present and Future. Trends Food Science Technology 14: 71-78.

Wuest SB, Lutcher LK, 2012. Soil Water Potential Requirement for Germination of Winter Wheat. Soil Science Society of America Journal 77: 279-283.

Zaefizadeh M, Jamaati-e-Somarin S, Zabihi-eMahmoodabad R, Khayatnezhad M 2011. Discriminate Analyses of The Osmotic Stress Tolerance of Different Sub-Convars of Durum Wheat During Germination. Advanced Environmental Biology 5: 74-80. 